\title{
Analysis of Industry 4.0 Readiness Indexes and Maturity Models and Proposal of the Dimension for Enterprise Information Systems
}

\author{
Josef Basl \\ University of Economics Prague, W. Churchill Sq. 4, 13067 Prague, Czech Republic \\ baslevse.cz
}

\begin{abstract}
The article deals with the analysis of available readiness indexes and maturity models for Industry 4.0. The main goal is to determine the extent to which these models and indexes are able to show a company's readiness from the point of view of its information system. Because this topic is not sufficiently dealt with in the available models there is a proposal focusing on the enterprise information system in the conclusion of this article.
\end{abstract}

Keywords: industry 4.0, Internet of Thing, maturity model, readiness, readiness index, enterprise information system, enterprise resource planning.

\section{Introduction - Industry 4.0 development at the peak of expectations}

At present, it is no longer necessary to focus primarily on explaining what Industry 4.0 is, what companies know about it, and what they plan to do in this area. This topic has been subjected to a great deal of attention recently [1],[2]. Our literature review has shown that over the past two years, attention has shifted mainly to the topic of readiness for Industry 4.0. This state of affairs is well copied by industry's internal development and positioning of Industry 4.0, and its individual factors. It is well reflected by Gartner's Hype Curve for predicting the development of technology, formulated for 2017 [25]. 


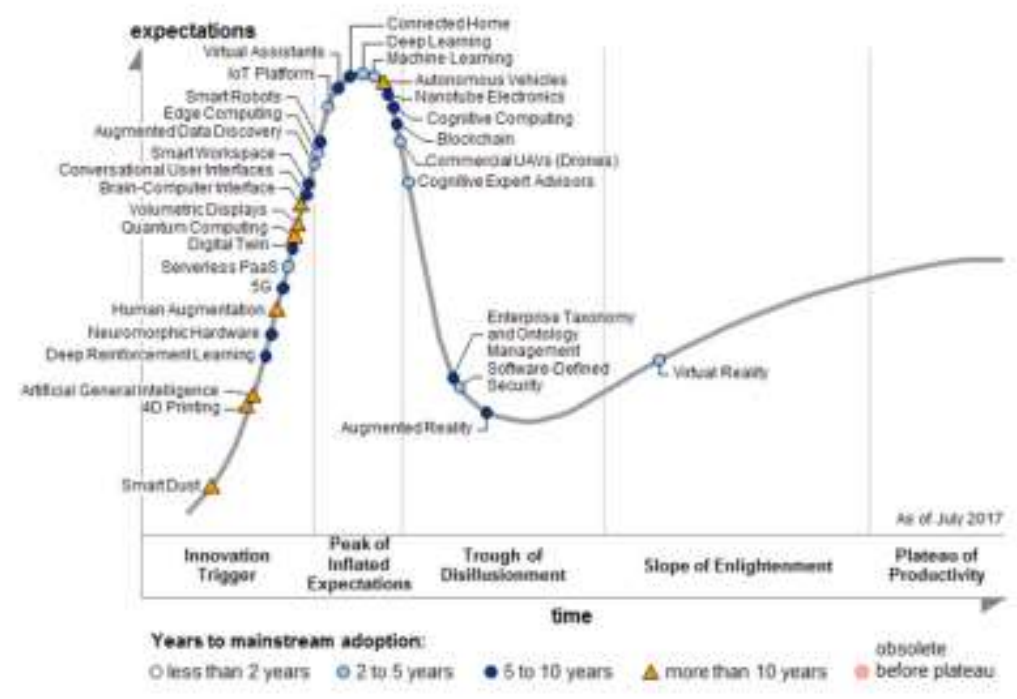

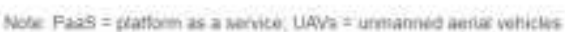

Seutce esmor culy 2017 )

Picture 1: Hype curve for 2017 [25]

Gartner's hype curve published for the year 2017 shows that Industry 4.0 in the form of its "core building elements" is either just ahead or even slightly behind the peak of expectations. Examples are IoT platforms, learning machines and autonomous vehicles. At the same time, those Industry 4.0 factors such as virtual and widespread reality are already at the final stage of the curve - the "Plateau of Productivity". At the end of 2017, Gartner furthermore confirmed in his forecasts the key IoT trend in industry 4.0. The term "IoT in Everything" predicts that "by 2020, IoT technology will be in $95 \%$ of electronics for new product designs. With the technology evolution around the IoT, it will be increasingly possible to add IoT features to every electronics-enabled product at minimal cost "[25].

This will all further exacerbate the need for good readiness of companies. 


\section{Theoretical Background - Enterprise information system in the Industry 4.0 paradigm}

\subsection{1 Readiness for Industry 4.0 of companies and its enterprise information systems}

The new and very important question concerning Industry 4.0 is: what is the readiness of the company and its enterprise information system? If a company wishes to answer such a question, a number of options are available today, including specially websites designed for this purpose [8]. Furthermore, a number of different models have been developed to assess a company's readiness for Industry 4.0 for the last two years [3],[4],[20],[21]. These models point not only to Industry 4.0 readiness [8], [14], [18], [19] but use different synonyms to describe the current status as digital readiness [11], digital enterprise [5], digital degree [12], digitization [10] or smart economy, for example, within Smart Dubai 2021 [27].

These models mostly focus on a certain list of available solutions, and they usually draw on the needs and design of their own model. This article is therefore not the first one to take a look at readiness models for Industry 4.0 but it is different in: - its scope (the number of models evaluated with the representation of many European countries)

- the depth (the comparisons made across Industry 4.0 and the individual dimensions surveyed)

- its specification (the suggestions for possible improvements specifically focusing on enterprise information systems, including ERP (Enterprise Resource Planning).

An overview of the analysed models is given in the third section of this paper.

\subsection{Readiness of companies and its enterprise information system in the wider "macro" context - readiness indexes}

A company always operates in a certain environment that, in a number of cases, is conditioned and decisive for its digitization and, in general, the ability to innovate. It is not only from the point of view of "micro", i.e. the company itself, but it is also necessary to look at it from the perspective of its surroundings from a "macro" level. This also includes, for example, one of the dimensions of the German reference model for Industry 4.0 known as the RAMI 4.0 [6]. The principles 4.0 at this "macro" level are known as Society 4.0. Within Society 4.0, besides Industry 4.0 there are many other areas focusing on the 4.0 development such as Farming 4.0 (focused on food production), Health 4.0 (focused on health services), Alma Mater 4.0 (focused on higher education) and last but not least eGovernment (or Government 4.0) and the smart city concept. All these "4.0" areas have their readiness models, like for example Health 4.0 [16] or Farming 4.0. In this article, however, we are concerned only with Industry 4.0 and the appropriate readiness models.

These "macro" evaluations are interesting because they point to the general preconditions for digitization of a country and its readiness for innovation, which are 
equally important for the development of Industry 4.0. The "macro" view covers the whole of society, or individual states. The best known readiness indexes are:

- NRI (Networked Readiness Index)

- GCI (Global Competitive Index)

- Score from the OECD Scoreboard

- Industry 4.0 Readiness Index by Berger [8].

\begin{tabular}{|c|c|c|c|c|}
\hline Index & Name of index & $\begin{array}{l}\text { Evaluation } \\
\text { authority }\end{array}$ & $\begin{array}{l}\text { Number of } \\
\text { metrics }\end{array}$ & $\begin{array}{l}\text { Number } \\
\text { of } \\
\text { countries }\end{array}$ \\
\hline NRI & $\begin{array}{l}\text { Networked } \\
\text { Readiness Index }\end{array}$ & WEF & 51 & 139 \\
\hline GII & $\begin{array}{l}\text { Global Innovation } \\
\text { Index }\end{array}$ & $\begin{array}{l}\text { Cornell } \\
\text { University, } \\
\text { INSEAD, WIPO }\end{array}$ & 81 & 127 \\
\hline Report & $\begin{array}{l}\text { Science, industry and } \\
\text { technology } \\
\text { Scoreboard }\end{array}$ & OECD & 200 & 31 \\
\hline $\begin{array}{l}\text { Industry } \\
4.0 \text { index }\end{array}$ & $\begin{array}{ll}\text { RB Industry } & 4.0 \\
\text { Readiness Index } & \\
\end{array}$ & Rolland Berger & $\begin{array}{c}\% \text { GDP } \\
\text { from industry } \\
\text { is the } 2 \text { nd } \\
\text { axis }\end{array}$ & 24 \\
\hline
\end{tabular}

Table. 1: Comparison of "macro" readiness indexes

A common factor of these "macro" evaluations is the large number of countries surveyed, and also the large scale (number) of assessed criteria. Many of these indexes did not appear in connection with start of Industry 4.0, but they have a longer-term data series. For example the NRI index has been known since 2002. From a methodological point of view, it is interesting that only one value is given to each country based on a readiness index. It provides the country with feedback and information about its position compared with other countries.

From the point of view of Industry 4.0, it is especially important for many authors to refer to the Industry 4.0 readiness index formulated by Roland Berger [8]. This index uses the Industry 4.0 readiness index in relation to the indicator of industry's share of a country's GDP in a two-dimensional arrangement.

To conclude the "macro" level for the purposes of this article, it is important that there is no special dimension for enterprise information systems, including ERP. 


\section{Methodology - aim of the research and resource data}

\subsection{1 Readiness of company and its enterprise information system, ERP mainly - based on maturity models for Industry 4.0}

The main goal of Industry 4.0 is further digitization, automation and robotization. These technologies have started to be implemented not today but already more than 40 years ago, e.g. in the form of FMS (Flexible Manufacturing Systems). Enterprise information systems ERP have played a key role in enterprise digitization for more than 30 years. ERP systems have also undergone a number of internal innovations over recent decades. Efforts have been made to modify their labelling from ERP to ERP II, respectively ERP III or postmodern ERP (defined by Gartner). Changes in ERP also came in 2014 at the CeBit as a key topic of the fair "ERP 2020".

Furthermore, most authors agree today that ERP systems will remain the "core" of enterprise information systems even in the future and will play an important role in enterprise 4.0 IT architecture because [24], [23], [5]: - ERP remains an important application in both horizontal and vertical integration - ERP integrates from a data point of view with IoT data, sensors, robotic workplaces - ERP becomes from a data point of view the basis for the further development of big data, business analysis and Artificial Intelligence - ERP can expand in the area of production, but also of logistics and of communication with the customer. The main question is whether ERPs are perceived in the models as a separate main dimension, or as a part of the IT. A related question is how many other evaluation dimensions, within the maturity model, are dedicated to IT aspects related to enterprise IS, e.g.:

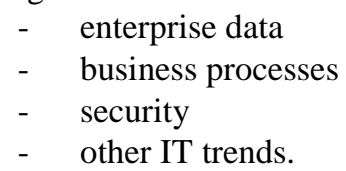

The authors of the analysed models are from universities, consultancy companies or national committees.

\subsection{Resource data - Industry 4.0 maturity models}

In the case of individual enterprise assessments, the situation is different from the one at the macro level (mentioned above). At the micro level it is not necessary to compare a large number of companies and dozens of indicators. The readiness models are mostly maturity models. Through the literature review, the following models were analysed:

- RAMI 4.0 (The Reference Architectural Model Industry 4.0) from BITCON VDI/VDE, ZVEI (Germany), 2015 [6] 
- $\quad$ Industry 4.0 Component Model - derivated from RAMI 4.0 and oriented on information technology [6] SIMMI 4.0 (System Integration Maturity Model Industry 4.0) from TU Dresden and TU Heilbronn (Germany), 2016 [7]

- $\quad$ IMPULS (Industry 4.0 Readiness) from VDMA and RWTH (Germany) [8]

- APM Maturity Model (Asset Performance Management Maturity Model from Capgemini [9]

- $\quad$ Industry 4.0 Readiness Evaluation for Manufacturing Enterprises from Academy of Science Hungary (Hungary), 2017 [21]

- Digitalization Degree of Manufacturing Industry from Uni Erlangen (Germany), 2017 [12]

- $\quad$ Stage maturity model in SME towards Industry 4.0

- $\quad$ Roadmap Industry 4.0 from Uni Caphenberg, 2017

- $\quad$ Industrie 4.0 MM (Assessment model for Industry 4.0) from Uni Ankara (Turkey), [13]

- M2DDM (Maturity Model for Data Driven Manufacturing) from Uni Stuttgart (Germany), 2017

- Industry 4.0/ Digital Operation Self Assessment from Price Waterhouse Coopers, 2016

- The Connected Enterprise Maturity Model from Rockwell Automation, 2014

- $\quad$ Pathfinder 4.0

- Industrie 4.0 Maturity Model from Acatech Studie

- Firma4.cz from the Czech Minister of Industry and Trade (Czech Republic), 2016 ,

These models are from different European countries, but mostly from Germany, and they have been mostly designed within the last two years.

\section{Analysis of enterprise information system dimension in maturity models for industry $\mathbf{4 . 0}$}

\subsection{Main dimensions and evaluation scale in analysed maturity models}

Available industry 4.0 maturity models have been analysed from this "ERP" perspective. In practice, this means the analysis of the categories (the applied dimensions) and the way of evaluating these dimensions (the applied rating scale). These two attributes are important for evaluating the enterprise maturity models for Industry 4.0. 
The following table shows the applied dimensions and evaluation scales:

\begin{tabular}{|c|c|c|c|}
\hline & Name of model & Dimension in model & Evaluation scale \\
\hline M1 & $\begin{array}{l}\text { RAMI } 4.0-\text { The } \\
\text { Reference } \\
\text { Architectural } \\
\text { Model Industry } 4.0\end{array}$ & $\begin{array}{l}\text { Life Cycle and Value Stream } \\
\text { Hierarchy levels Layers (3D } \\
\text { model) }\end{array}$ & NA \\
\hline M2 & \begin{tabular}{|lr} 
Industry & 4.0 \\
Component & Model
\end{tabular} & $\begin{array}{l}\text { Relation to the RAMI } 4.0 \text { in } \\
\text { technology dimension }\end{array}$ & NA \\
\hline M3 & $\begin{array}{l}\text { SIMMI } 4.0- \\
\text { System Integration } \\
\text { Maturity Model } \\
\text { Industry } 4.0\end{array}$ & $\begin{array}{l}\text { 1-Vertical Integration 2- } \\
\text { Horizontal Integration 3- } \\
\text { Digital product development } \\
\text { 4-Cross-sectional technology } \\
\text { criteria }\end{array}$ & $\begin{array}{l}\text { 1-Basic digitalization level } \\
\text { 2-Cross-departmental } \\
\text { digitalization 3-Horizontal } \\
\text { and vertical digitalization 4- } \\
\text { Full digitalization 5- } \\
\text { Optimized full digitalization }\end{array}$ \\
\hline M4 & $\begin{array}{lr}\text { IMPULS } & - \\
\text { Industrie } & 4.0 \\
\text { Readiness } & \end{array}$ & $\begin{array}{l}\text { 1-Strategy and organization } \\
\text { 2-Smart Factory 3-Smart } \\
\text { Operations 4- Smart Products } \\
\text { 5-Data driven Services 6- } \\
\text { Employee }\end{array}$ & $\begin{array}{l}\text { 0-outsider 1-Beginner 2- } \\
\text { Intermediate 3- Experienced } \\
\text { 4-expert 5-Top performer }\end{array}$ \\
\hline M5 & $\begin{array}{l}\text { APM - Asset } \\
\text { Performance } \\
\text { Management } \\
\text { Maturity Model }\end{array}$ & $\begin{array}{|lr|}\text { 1-Asset } & \text { Information } \\
\text { Management } & \text { 2-Process } \\
\text { Management } & \text { 3-Reliability } \\
\text { and Performance 4- } & \text { 4- } \\
\text { Governance and Standards 5- } \\
\text { People and Culture } \\
\begin{array}{l}\text { Management 6-Tools and } \\
\text { Technologies }\end{array} \\
\end{array}$ & $\begin{array}{l}\text { 0-Ad hoc/ initial } 1 \\
\text { Defined/Preliminary } \\
\text { Adoption } \\
\text { Compliant/normative } \\
\text { Evlolving/Integrated } \\
\text { Enterprise } \\
\text { Excellence }\end{array}$ \\
\hline M6 & $\begin{array}{ll}\text { Industry } & 4.0 \\
\text { Readiness } & \\
\text { Evaluation for } \\
\text { Manufacturing } & \\
\text { Enterprises } & \end{array}$ & $\begin{array}{l}\text { 1-Strategy 2-Leadership 3- } \\
\text { Offered product and Services } \\
\text { 4-Customers 5-Company } \\
\text { Culture 6-people 7-Technical } \\
\text { aspects (production) 8- } \\
\text { Critical areas of intervention } \\
\end{array}$ & $\begin{array}{l}\text { Measured in } 2 \text { aspects by } \\
\text { discrete scale: 1- Rating of } \\
\text { Level of Completion 2- } \\
\text { Rating of Relevance for } \\
\text { Successful Implementation }\end{array}$ \\
\hline M7 & $\begin{array}{l}\text { Digitalization } \\
\text { Degree of } \\
\text { Manufacturing } \\
\text { Industry }\end{array}$ & $\begin{array}{l}\text { 1-Level of automation 2- } \\
\text { degree of automation }\end{array}$ & $\begin{array}{l}\text { 1- mainly made by hand 2- } \\
\text { partly automated 3-highly } \\
\text { automated 4-sel-regulating } \\
\text { 1-mainly manually 2-partly } \\
\text { automated } \\
\text { automated }\end{array}$ \\
\hline M8 & $\begin{array}{lr}\text { The } & \text { Singapore } \\
\text { Smart Industry } \\
\text { Readiness index }\end{array}$ & $\begin{array}{l}\text { 3-building blocks (process, } \\
\text { technology, organization) } \\
\text { and } 8 \text { pillars (operations, } \\
\text { supply chain, product } \\
\text { lifecycle, automation, } \\
\text { connectivity, intelligence, } \\
\text { talent readiness, structure } \\
\text { management) }\end{array}$ & NA \\
\hline
\end{tabular}




\begin{tabular}{|c|c|c|c|}
\hline M9 & $\begin{array}{l}\text { Stage maturity } \\
\text { model in SME } \\
\text { towards Industry } \\
4.0\end{array}$ & $\begin{array}{l}\text { 1-Envision, 2-Enable, 3- } \\
\text { Enact }\end{array}$ & $\begin{array}{l}\text { 1-Initial, 2-Managed, 3- } \\
\text { Defined, 4-Transfom, 5- } \\
\text { Detailed BM }\end{array}$ \\
\hline M10 & $\begin{array}{l}\text { Roadmap Industry } \\
4.0\end{array}$ & $\begin{array}{l}\text { 1-Acceptance and } \\
\text { Application of new } \\
\text { Technology and Media, 2- } \\
\text { Professional Competence, 3- } \\
\text { Learning Competence, 4- } \\
\text { Corporate Strategy, 5-HR } \\
\text { Development Strategy, 6- } \\
\text { Organisation and } \\
\text { Democratization, 7-Flexible } \\
\text { Working Models, 8-Health } \\
\text { and Safety, 9-Information } \\
\text { and Communication, 10- } \\
\text { Employer Branding, 11- } \\
\text { Change Management, 12- } \\
\text { Process Orientation, 13- } \\
\text { Knowledge management }\end{array}$ & 5 maturity levels \\
\hline M11 & $\begin{array}{l}\text { Industry 4.0-MM - } \\
\text { Assessment model } \\
\text { for Industry } 4.0\end{array}$ & $\begin{array}{l}\text { 1-Asset Management, 2-Data } \\
\text { Management, 3-Application } \\
\text { Management, 4- } \\
\text { Organizational Alignment, 5- } \\
\text { Process Transformation } \\
\end{array}$ & $\begin{array}{l}\text { 0-Incomplete, 1-Perfomed, } \\
\text { 2-Managed, 3-Established, } \\
\text { 4-Predictable, 5-Optimizing }\end{array}$ \\
\hline M12 & $\begin{array}{l}\text { M2DDM - } \\
\text { Maturity Model for } \\
\text { Data Driven } \\
\text { manufacturing }\end{array}$ & $\begin{array}{l}\text { 1-Data Storage and Compute, } \\
\text { 2-Service-oriented } \\
\text { Architecture, 3-Information } \\
\text { Integration, 4-Digital Twins, } \\
\text { 5-Advanced Analytics, 6- } \\
\text { Real-time Capabilities }\end{array}$ & $\begin{array}{l}\text { 0-Nonexistent } \\
\text { integration, 1-Data and } \\
\text { System Integration, 2- } \\
\text { Integration of Cross-Life- } \\
\text { cycle Data, 3-Service } \\
\text { Orientation, } \\
\text { Twins, 5-Self-optimising } \\
\text { Factory } \\
\end{array}$ \\
\hline M13 & $\begin{array}{l}\text { Maturity model for } \\
\text { assessing Industry } \\
4.0 \text { readiness and } \\
\text { maturity of } \\
\text { manufacturing } \\
\text { enterprises }\end{array}$ & $\begin{array}{l}\text { 1-Strategy, 2-Leadership, 3- } \\
\text { Customers, 4-Products, 5- } \\
\text { Operations, 6-Culture, 7- } \\
\text { People, 8-Govenrnance, 9- } \\
\text { Technology }\end{array}$ & NA \\
\hline M14 & $\begin{array}{lr}\text { Industry } & 4.0 / \\
\text { Digital Operation } \\
\text { Self-Assessment }\end{array}$ & $\begin{array}{l}\text { 1-Business Models, Product } \\
\text { and Service Portfolio 2- } \\
\text { Market and Customer Access } \\
\text { 3-Value Chain and Processes } \\
\text { 4-IT architecture 5- } \\
\text { Compliance, Legal, Risk, } \\
\text { Security and Tax 5- } \\
\text { Organisation Culture }\end{array}$ & $\begin{array}{|lr|}\text { 1-Digital Novice } & \text { 2-Vertical } \\
\text { Integrator } & \text { 3-Horizontal } \\
\text { Collaborator } & \text { 4-Digital } \\
\text { Champion } & \end{array}$ \\
\hline
\end{tabular}




\begin{tabular}{|c|c|c|c|}
\hline M15 & $\begin{array}{l}\text { The Connected } \\
\text { Enterprise Maturity } \\
\text { Model }\end{array}$ & NA & \begin{tabular}{lrr}
\multicolumn{3}{l}{-Assessment 2- Secure and } \\
upgraded networks and \\
controls & 3-Defined & and \\
organised & working & data \\
capital 4-Analytics & $5-$ \\
Collaboration &
\end{tabular} \\
\hline M16 & $\begin{array}{l}\text { firma4.cz }- \text { Firm } \\
\text { digital maturity }\end{array}$ & $\begin{array}{l}\text { 1-Leadership, HR, openness, } \\
\text { firm culture, 2-Business } \\
\text { model, customer orientation a } \\
\text { digital product, 3-Operational } \\
\text { model, digital environment } \\
\text { and management, 4- } \\
\text { Technology, 5-Data and data } \\
\text { culture }\end{array}$ & 5 levels \\
\hline M17 & Pathfinder 4.0 & $\begin{array}{l}\text { 1-Management } \\
\text { Leadership 2-Organisation } \\
\text { and HR 3-Technology and } \\
\text { infrastructure 4-Market } \\
\text { Awareness Perception }\end{array}$ & NA \\
\hline M18 & $\begin{array}{l}\text { Industrie } 4.0 \\
\text { Maturity Model }\end{array}$ & NA & $\begin{array}{l}\text { 1-Computerization } \\
\text { Connectivity } 3 \text {-Security } 4- \\
\text { Transparency } 5 \text {-Forecasting } \\
\text { 6-Adaptability }\end{array}$ \\
\hline
\end{tabular}

Table 2: Overview of Dimensions and Model Scale Assessment Scale for Industry 4.0 Maturity Models

The models listed in the above table 2 have been received based on the systematic literature research. They are order from M1 (model 1) to M18 (model 18) based on the importance, frequency and relevance to the searched topic "industry 4.0 maturity model". Description of the dimensions and evaluate scales was given from the model description. Some of the models have their acronyms and some not. Therefore model were listed shortly in the previous chapter before mentioned in the table 2 .

\subsection{Key findings from analysed maturity models}

The main findings from the available maturity models follow. The models are very complex but they do not contain detailed information about enterprise information systems as a separate dimension. Most models deal with enterprise-wide topics such as:

- Strategy (M6, M10, M13)

- Leadership (M4, M6, M13)

- Corporate culture (M5, M6,M14 )

- Human Resources (M4, M5).

Most models have a Technology dimension (M3, M4, M5, M10, M12) and then the IT in the company is spread out in dimensions like: 
- Digital product

- Digital processes

- Digital control.

The scales used are largely built on CMM (Capability Maturity Model) principles, but some use digitization scale (M3, M7) or evaluating the enterprise as a whole (M4, M14) From the point of view of specialization, maturity models range (scale interval) from focusing on the whole enterprise to focusing on digitization, or concentrating on IT technologies.

Last but not least, it was possible to identify an analytical tool evaluating the current state of readiness of a company and its maturity for Industry 4.0, but some also focused on the follow-up of the 'roadmap' [15], [22].

\subsection{Proposal of enterprise information system dimension in a maturity model}

It is clear that all dimensions in maturity models are highly aggregated and thus they are not explicitly prepared for evaluating the readiness of the enterprise information system and ERP system. Therefore, it is necessary to give them a more detailed view and to create a separate dimension to monitor it in more detail.

First to specify the special "enterprise information system" dimension, it is possible to apply the trends in the following structure:

- Applications - ERP, SME, APS, WMS, mobile apps, big data, AI

- Connectivity - broadband, social networks, cloud,

- Digitization - IoT, wearables, robotics, VR and AR, digital twins

- Cross sectional - security for example.

Secondly to describe the 'application' sub dimension in more detail the following structure can be used:

- Systems of record - ERP, CRM,

- Systems of differentiation - WMS, MES, APS, JIS

- Systems of innovation - apps based on industry 4.0 opportunities

Thirdly, the ERP could be further divided into even lower levels and could have their own maturity "steps":

- Full horizontal integration of ERP

- Full vertical integration of ERP

- Integration into data from digital twins

- The use of artificial intelligence in ERP in autonomous decision making and full automation

This approach emphasises the importance of the main ERP data, which was already pointed out by E. Goldratt in his book 'Necessary but not sufficient' [26]. 


\section{Conclusion and final recommendations}

Analysis of the readiness indexes and the maturity models showed:

- there is a low description of dimensions for enterprise information systems and ERP applications. This article has tried to contribute to this gap.

- $\quad$ there are still not yet fully developed branch specified solutions for Industry maturity models for the automotive, food and chemical industries, etc., and for different types of companies such as SMEs.

The analysis also pointed out that the question of whether there is better access to Industry 4.0 using the readiness index or maturity models is not properly formulated. These two approaches do not stand up against each other, but each one provides important information, drawing on other data and different data processing.

\section{References}

1. Basl, J., Sasiadek, M.: Comparison of Industry 4.0 Application Rate In Selected Polish and Czech Companies, IDIMT conference, Podebrady, 2017

2. Basl, J.: Penetration of Industry 4.0 Principles into ERP Vendors' Products and Services A Central European Study, CONFENIS conference, Shang Hai, 2017

3. Schuch, G., Anderl, R., Geusemeier, J., Hompel, M., Wahlster, W.: Industrie 4.0 Maturity Index - Die digitale Transformation von Unternehmen gestalten, acatech STUDIE, Frauenhofer, acatech

4. Schumacher, A.,Erol, S., Sihn, W.: A maturity model for assessing Industry 4.0 readiness and maturity of manufacturing enterprises, Elsevier, 2016

5. Industry 4.0: Building the digital enterprise, Global Industry 4.0 survey, Price Waterhouse Coopers, 2016

6. Koschnick, G.: The Reference Model Industrie 4.0 (RAMI 4.0), ZWEI - Die Elektroindustrie, 2015

7. Leyh, Ch., Schaffer, T., Bley, K., Forstenhausler, S.: SIMMI 4.0 - A Maturity Model for Classifying the Enteerprise-wide IT and Software Landscape Focusing on Industry 4.0, Proceedings of the Federated Conference on Computer Science and Information Systems, pp. 1297-1302, IEEE, 2016

8. Model: Industry 4.0 Readiness Online Self-Check for Business, https://www.industrie40readiness.de/?lang=en, available April 282018

9. Dennis, M., Ramaswamy, Ch., Ameen, M.N., Jayaram, V. : Asset Performance Management Maturity Model, BCG Perspective, Capgemini, 2017

10. Bley, K., Leyh, Ch., Schaffer, T.:Digitalizastion of German Enterprise in the Production Sector - Do they know how ,digitized“ they are? Twenty-second Americas Conference on Information Systems, San Diego, 2016

11. De Carolis, A., Macchi, M., Negri, E., Terzi, S.: A Maturity Model for Assessing the Digital Readiness of Manufacturing Companies, Advanced in Production Management Systems, The path to Intelligent, Collaborative and Sustainable Manufacturing, Springer, 2017

12. Bogner, E., Voelklein, T., Schroedel, O., Franke, J.: Study Based Analysis on the Current Digitalisation Degree in the Manufacturing Industry in Germany, Elsevier, 2016 
13. Gokalp, E., Sener, U., Eren, E.: Development of an Assessment Model for Industry 4.0: Industry 4.0-MM, Middle East Technical University, Ankara, TurkeyThe 9th CIRP IPSS Conference:Circular Perspectives on Product/Services-Systems, Elsevier, 2017

14. Exner, K., Zimpfer, R., Stark, R.: Maturity model and action recommendation: a PSS capability self-assessment tool for companies, TU Berlin,

15. Pessl, E., Sorko, S.R., Mayer, B.: Roadmap Industry 4.0 - Implementation Guideline for Enterprises, International Journal of Science, Technology and Society, 2017

16. Carvalho, J.V., Rocha, A., Abreu A.: Maturity Models of Health Information Systems and Technologies: a Literature Review, Journal of Medical Systems, Springer Science+Business Media New York, 2016

17. Hermann, M., Pentek, T., Otto, B.: Design Principles for Industrie 4.0 Scenarios: A Literature Review, Working Paper No. 1/2015,Technische Universitat Dortmund, 2015

18. Viharos, Z.J., at all.: Non-comparative, Industry 4.0 Readiness Evaluation for Manufacturing Enterprises, 15th IMEKO TC10 Workshop on Technical Diagnostics, Technical Diagnostics in Cyber-Physical Era, Budapest, Hungary, 2017

19. Liao, Y., Deschamps, F., Freitas Rocha Loures, E., Ramos, L.F.P.: Past, present and future of Industry 4.0 - systematic literature review and research agenda proposal

20. Grangel-Gonzáles, I. at all.: Towards a Semantic Administrative Shell for Industry 4.0 Components,

21. Halenár, I., Juhasova, B., Juhas, M.: Design of Communication Scheme in a Modern Factory in accorardance with the Standard of Industry 4.0, Research paper, Slovak University of Technology, Bratislava, 2016

22. Shinohara, A., C. at all: Critical Success Factors for Digital Manufacturing Implementation in the Context of Industry 4.0, Proceedings of the 2017 Industrial and Systems Engineering Conference

23. Muller, J. M., Kiel, D., Voigt, K.: What Drive the Implementation of Industry 4.0? The Role of Opportunity and Challenges in the Context of Sustainability, Journal of Sustainability, 2018

24. Stojkovic, Z., Veza, I., Bosnjak, I.: A Concept of Information System Implementation (CRM and ERP) within Industry 4.0, 26th DAAAM International Symposium on Intelligent Manufacturing and Automation, Vienna, Austria, 2016

25. Gartner trends 2018: https://www.gartner.com/smarterwithgartner/gartner-top-strategicpredictions-for-2018-and-beyond/, Gartner Top Strategic Predictions for 2018 and Beyond October 3, 2017

26. Goldratt, E. et al.: Necessary But Not Sufficient: A Theory of Constraints Business Novel, 2000

27. Project: Smart Dubai - Preparing Dubai to embrace the future, now, https://2021.smartdubai.ae/, available 26.04:2018 